\title{
PENDIDIKAN POLITIK DAN PARTISIPASI MASYARAKAT DESA MEKAR JAYA
}

\author{
Tutik Haryani \\ Departement of Social and Political Science, FISIP Universitas PGRI Palangka Raya \\ (email: tutikharyaniupp@gmail.com) \\ Seto Hadi \\ Fakultas IImu Sosial dan IImu Politik Universitas PGRI Palangka Raya
}

\begin{abstract}
Abstrak
Penelitian ini bertujuan; a) Untuk menggambarkan dan menganalisa pendidikan politik dan pengaruhnya terhadap partisipasi politik masyarakat di Desa Mekar Jaya Kecamatan Parenggean berdasarkan latar belakangnya. b) Untuk menggambarkan dan menjelaskan bagaimana dan sampai dimana partisipasi politik masyarakat Desa Mekar Jaya Kecamatan Parenggean dalam pemilihan Presiden dan Wakil Presiden. c) Untuk mengetahui bagaimana serta apa saja faktor yang mempengaruhi partisipasi politik masyarakat di Desa Mekar Jaya Kecamatan Parenggean.

Penelitian ini menggunakan metode kualitatif dengan jenis penelitian deskriptif yang bertujuan untuk menggambarkan bagaimana partisipasi masyarakat pada pilpres 2019, di Desa Mekar Jaya Kecamatan Parenggean.

Hasil Penelitian: a) Pendidikan serta partisipasi politik masyarakat di Desa Mekar Jaya Kecamatan Parenggean Kabupaten Kotawaringin Timu Terbilang kurang baik karena kurangnya masyarakat ikut serta dalam menggunakan hak suara mereka diakibatkan tingkat pendidikan serta partisipasi politik masyarakat di Desa Mekar Jaya tersebut kurang memahami apa itu pesta demokrasi yang sebenarnya, mereka lebih memilih golput tidak menggunakan hak suara nya di bandingkan ikut serta dalam pemilihan. b) Faktor- faktor yang mempengaruhi partisipasi politik yang kaitannya dengan konteks sosial. Kongkretnya, memilih seseorang dalam pemilihan umum dipengaruhi latar belakang demografi dan sosial ekonomi, seperti jenis kelamin, tempat tinggal (kota-desa), pekerjaan, pendidikan, kelas, pendapatan dan agama. Faktor fisikologi merujuk pada persepsi pemilih atas partai-partai yang ada atau keterkaitan emosional pemilih terhadap partai tertentu serta faktor pendekatan rasional melihat kegiatan memilih sebagai produk kalkulasi untung dan rugi.
\end{abstract}

Kata kunci : Pendidikan Politik, Partisipasi Masyarakat 


\section{Pendahuluan}

Sebagai perwujudan bukti sebuah negara menerapkan sistem demokrasi ialah dengan menggelar perhelatan pemilihan umum. Sistem pemilihan umum merupakan salah satu sistem atau kelembagaan penting di dalam sistem demokrasi. Penerapan sistem pemilihan umum di Indonesia masih terbilang belum sepenuhnya mampu merepresentasikan kehendak masyarakat Indonesia baik di daerah perkotaan terlebih-lebih di daerah pedesaan atau dusun sekalipun. Masyarakat Indonesia pada umumnya telah mampu mengikuti proses pemilu dan menghormati hasil pemilu, namun pemilu di Indonesia masih banyak menghadapi kendala-kendala dalam pelaksanaannya. Pemilu menjadi indikator yang paling mudah dalam menentukan sebuah negara tersebut demokratis atau tidak, karena Pemilu memberikan sebuah momentum kepada masyarakat untuk menentukan arah perkembangan sebuah negara. (Iqbal M. Mujtahid, 2013) .

Begitu pula yang terjadi pada proses sistem demokrasi yang terjadi pada Desa Mekar Jaya dalam pilkada serentak 2018 kemarin dimana jumlah partisipasi masyarakat mengalami penurunan angka pemilih dari tahun pemilihan kemarin, dimana ini diakibatkan kurangnya pemahaman serta pendidikan politik masyarakat dalam pemilihan Kepala Desa setempat.

Kendala utama dalam pemilu yaitu pemberian informasi kepada masyarakat mengenai proses-proses utama dalam pemilihan kepala daerah. Perlunya peningkatan informasi kepada masyarakat mengenai proses pemilu yang penting seperti informasi kepada masyarakat mengenai proses pemilu yang penting seperti informasi pra kandidat, proses pencalonan kandidat, proses penghitungan suara sampai calon terpilh, kampanye pemilu yang dilakukan, cara masyarakat mendaftar diri sebagai pemilih, tata cara yang tepat memadai surat suara, dan dimana serta kapan harus memilih. (Iqbal M. Mujtahid, 2014)

Menjadi momentum dan tugas pokok dari Komisi Pemilihan Umum (KPU). Salah satu tugas dan kewenangan KPU yaitu melaksanakan sosialisasi penyelenggaraan pemilu serta tugas dan kewenangan KPU kepada masyarakat. Pemilih merupakan ujung tombak untuk menentukan calon yang terpilih pada proses Pemilu. Oleh karena itu, banyak permasalahan yang muncul seperti; money politic, penggelembungan suara, pemilih ganda, pemalsuan daftar mata pilih, yang dilakukan oleh pihak penyelenggara Pemilu. Hal tersebut merupakan bentuk dari penyalahgunaan kekuasaan dalam Pemilu, yang seharusnya tidak dilakukan. Kurangnya pengetahuan masyarakat akan pentingnya suara mereka sebagai pemilih menimbulkan keprihatinan mendalam. Dimana masyarakat sekarang ini sudah menjadi masyarakat yang apatis terhadap pemerintah.

Penerapan sistem pemilihan umum di Indonesia masih terbilang belum sepenuhnya mampu merepresentasikan kehendak rakyat Indonesia. Pasca reformasi perubahan sistem pemilu yang sebelumnya menggunakan sistem pemilihan proporsional tertutup menjadi proporsional terbuka memang relevan bagi sosio-kondisi Indonesia sendiri dan tuntutan rakyat untuk menyelenggarakan pemilihan secara langsung, umum, bebas, rahasia, jujur, dan adil. Dengan kata lain sangat diharapkan adanya transparansi terhadap penyelenggaraan pemilihan umum. Penilaian sistem pemilu dapat

\section{Jurnal Sociopolitico}


dilihat dari berbagai sudut pandang yaitu kondisi sistem ekonomi, kondisi lembagalembaga politik, proses pemungutan suara, proses pemilihan kepala daerah, tatacara pemilihan, tingkah laku masyarakat dalam memilih, partisipasi perempuan dalam partai politik, pendapat masyarakat mengenai demokrasi, dan munculnya masalah-masalah baru dalam pemilu. Kandidat yang maju telah diseleksi sebelumnya karena harus memenuhi persyaratan dan sistem sesuai peraturan yang berlaku. Sistem pemilu saat ini merencanakan bayak pemilu kepala daerah sehingga dalam melakukan proses pemungutan suara diperlukan informasi dan tatacara pemilu yang efektif kepada masyarakat luas. (Iqbal M. Mujtahid, 2013).

Muncullah sebuah tawaran untuk penyelesaian permasalahan dalam proses pemilu khususnya dalam suatu daerah desa yaitu dengan pendidikan politik terpadu. Pendidikan politik terpadu merupakan jawaban intelektual dari persoalan pemilu yang semakin lama semakin tidak jelas arahnya dan semakin banyak penyimpangan yang terjadi. Pendidikan politik bagi pemilih perlu mendapatkan fokus yang jelas. Ini terkait dengan proses segmentasi pendidikan pemilih. Pemilih pemula merupakan segmentasi penting dalam upaya melakukan pendidikan bagi pemilih dan tentunya pendidikan bagi pemilih pemula ini tidak hanya dilakukan ketika masuk usia pilih. Kurangnya informasi penting mengenai proses pemilihan merupakan masalah yang harus ditangani secara serius karena hal ini harus dimengerti oleh masyarakat yang memilih dalam pemilu. Untuk meningkatkan partisipasi masyarakat dalam pemilu diperlukan sumber informasi seperti brosur, iklan di media cetak/internet, surat- surat melalui pos, kampanye iklan di radio, poster, debat/dialog kandidat pemilu dan lain-lain. Jika pemilih secara keseluruhan sudah memiliki pengetahuan mengenai politik dan pemilu, bukan tidak mungkin korupsi dapat dihindarkan bahkan dihilangkan. Karena masyarakat akan menjadi pengawas atas segala penyelenggaraan kegiatan negara, sesuai dengan kedaulatan berada ditangan rakyat.

Berkaitan dengan Negara-negara baru Samuel P. Huntington dan Joan M. Nelson dalam No easy choice: political participation in developing countries member tafsir yang lebih luas dengan memasukkan secara eksplisit tindakan illegal dan kekerasan. Partisipasi politik adalah kegiatan warga Negara yang bertindak secara pribadi-pribadi, yang dimaksud untuk memengaruhi pembuatan keputusan oleh pemerintah. Partisipasi bisa bersifat individual atau kolektif, terorganisir atau spontan, mantap atau sporadic, secara damai atau dengan kekerasan, lagal atau illegal, efektif atau tidak efektif. (Miriam Budiarjo, 2008).

Di Negara-negara demokrasi konsep partisipasi politik bertolak dari paham bahwa kedaulatan ada ditangan rakyat, yang dilaksanakan melalui kegiatan bersama untuk menetapkan tujuan-tujuan serta masadepan masyarakat itu dan untuk menentukan orang-orang yang akan memegang tampuk pimpinan. Jadi partisipasi politik merupakan pengecualian dari penyelenggaraan kekuasaan politik yang abash oleh rakyat. Anggota masyarakat yang berpartisipasi dalam proses politik, misalnya melalui pemberian suara atau kegiatan lain, terdorong olrh keyakinan bahwa melalui kegiatan bersama itu kepentingan mereka akan tersalur atau sekurang-kurangnya di perhatikan, dan bahwa mereka sedikit

\section{Jurnal Sociopolitico}


banyak dapat memengaruhi tindakan dari mereka yang berwenang untuk membuat keputusan yang mengikat. Dengan kata lain, mereka percaya bahwa kegiatan mereka mempunyai efek politik (political efficacy) (Miriam Budiarjo, 2008).

\section{Metode Penelitian}

Penelitian ini menggunakan metode kualitatif dengan jenis penelitian deskriptif yang bertujuan untuk menggambarkan bagaimana partisipasi masyarakat pada pilpres 2019, di Desa Mekar Jaya Kecamatan Parenggean

\section{Hasil dan Pembahasan}

\section{Pendidikan Politik Di Desa Mekar Jaya}

Pendidikan politik merupakan dua elemen yang penting dalam sistem sosial politik di suatu negara, baik negara maju maupun negara berkembang. Keduanya sering dilihat sebagai bagian-bagian yang terpisah, yang satu sama lain tidak memiliki hubungan apa-apa. Padahal, keduanya bahu-membahu dalam proses pembentukan karakteristik masyarakat di suatu negara demokrasi. Lebih dari itu keduanya satu sama lain saling menunjang dan saling mengisi. Lembaga- lembaga dan proses pendidikan politik berperan penting dalam membentuk perilaku politik masyarakat di negara tersebut.

Terlebih-lebih pada pendidikan politik juga sangat penting dalam tingkat kesadaran suatu masyarakat dalam pesta demokrasi dimana dengan adanya pendidikan politik yang baik, sosialisasi politik yang merata hingga kesadaran politik masyarakat di suatu desa terkhusus di suatu dusun itu terbangun, namun berdasarkan fakta yang terjadi di lapangan dalam pesta Demokrasi pada pilpres kemarin banyak masyarakat yang tidak turut andil dalam melaksanakan pesta demokrasi tersbut, hingga partisipasi atau tingkat kesadaran memilih dan menggunakan hak suara mereka itu menurun di akibatkan kurangnya pengetahuan yang dimiliki, pengaruh pendidikan politik yang tidak merata dikarenakan hanya masalah sepeleh dan tugas dari KPU mengenai informasi dan sosialisasi masalah pemilihan itu tidak terlaksana ini di buktikan pada pesta Demokrasi yang terjadi di Desa Mekar Jaya, Kecamatan Parenggean, Kabupaten Kotawaringin Timur, pada pemilihan Presiden dan Wakil Presiden 2019 kemarin.

\section{Tingkat pendidikan politik dalam dua (2) RW di Desa Mekar Jaya \\ 1) RW 001}

Terkait masalah pendidikan politik serta partisipasi politik masyarakat di RW 001 mengenai ke ikut sertaan masyarakat tersebut dalam pesta demokrasi itu terbilang sangat baik, dikarenakan di RW infrastruktur mengenai listrik di RW tersebut sudah ada jadi masyarakat sangat gampang meng-update mengetahui pesta demokrasi melalui media komunikasi saja, baik itu melalui TV ataupun Telpon genggam seperti halnya apa yang dikatakan oleh Pak Sumardi selaku ketua RW 001

"jelas lah kalau kita bicara masalah pengaruh pendidikan serta partisipasi politik di dusun kami yah jelas lah besar, karna rata-rata masyarakat di dusun ini memiliki TV dan Hadpone untuk selalu abdet mengenai pesta demokrasi kaya kemarin, apalagi pihak Panwaslu kan dan KPU sering mengadakan sosialisasi ketika akan di adakan nya lagi pemilu kaya pilpres

\section{Jurnal Sociopolitico}


2019 kemarin, jadi bodoh lah masyarakat sini kalau mereka tidak menggunakan hak suaranya dalam pemilu apalagi dengan alasan tidak tahu mengenai masalah pencoblosan." (hasil wawancara dengan pak Sumardi).

Pendidikan politik di RW 001 itu maju dikarenakan kesadaran pendidikan masyarakat juga para orang tua mengenai pendidikan anak-anaknya tinggi, ditambah dengan sudah mulai banyaknya masyarakat di RW 001 tersebut yang menyelesaikan studi sarjananya di luar daerah, hingga inilah yang menyebabkan pendidikan politik masyarakat RW 001 itu terbilang besar. Begitu pula pada RW 002.

\section{2) RW 002}

Begitu pula pada Dusun Nahung kesadaran akan pendidikan politik serta partisipasi politik masyarakat pada pilpres 2019 tersebut terbilang tinggi dikarenakan kesadaran masyarakat mengenai pendidikan di tambah dengan adanya TV, Radio dan Telpon yang menjadi faktor pendukung dalam mengetahui segala hal yang ingin mereka ketahui apalagi dalam hal pemilu, penggunaan hak suara, pentingnya memilih, menggunakan hak suara mereka, siapa yang bagus latar belakang pendidikan nya yang mencalonkan itu semua mereka bisa dapatkan melalu Media, seperti halnya apa yang dikatakan oleh Pak Yasmo Rejo selaku Ketua RW 002.

"masalah pendidikan politik apalagi masalah partisipasi masyarakt di $R W$ 002 sini jelas lah lumayan tinggi tidak sama pada jaman saya masi muda dulu belum ada yang namanya media kaya TV, telpon dan lain-lain jadi kalau ada pemilu yah kami semua tidak tau, kami malah sibuk di kebun jg merawat hewan ternak kami, tapi sekarang bedalah, sekarang suda ada yang namanya media jadi masyarakat dengan gampang tau kapan pemilu, apa pentingnya suara kita dan lain sebagainya, ditambah juga sekarang kan suda mulai banyak sekolah negeri yang di bangun jadi anak-anak di RW ini dengan nyamannya melaksanakan pendidikan mereka sampai tinggi yang jelas jangan kaya kita-kita ini yang pendidikannya hanya sampai SD saja.")hasil wawancara dengan PakYasmo Rejo)

Dari pembicaraan diatas jelas bahwa infrastruktur dalam bentuk media, listrik dan lain sebagainya itu menjadi kendala dalam pendidikan serta partisipasi politik masyarakat di suatu daerah Desa terkhusus pada suatu RW.

\section{Bentuk-bentuk pendidikan politik di Desa Mekar Jaya}

Sosialisasi politik yang dilakukan oleh pihak KPU atau lembaga politik di Desa Mekar Jaya pada pilpres 2019 kemarin itu tidak merata sehingga sosialisasi tersebut hanya di rasakan oleh beberapa RW saja, dalam hal ini sosialisasi politik tersebut hanya di rasakan oleh sebagian RW atau RT saja dalam Desa Mekar Jaya tersebut, namun ada satu RW di Desa mekar Jaya tersebut tidak pernah sama sekali tersentuh sosialisasi politik atau lembaga politik, sehingga inilah yang menjadi faktor rendahnya partisipasi politik di RW/RT tersebut dikarenakan karena tdk adanya sosialisasi politik oleh pihak KPU, di tambah dengan daerah tersebut tidak dialiri listrik sehingga masyarakat di

\section{Jurnal Sociopolitico}


RW/RT tersebut tidak dapat mengetahui dan medapat informasi dari media televisi.

Sehingga bentuk pendidikan politik atau sosialisasi mengenai politik masyarakat di RW 003 tersebut itu di sampaikan secara mulut ke mulut atau face to face juga sosialisasi tersebut pula di terima dari pemuka agama atau imamimam mesjit setempat, begitu pula apa yang dikatakan oleh Pak Misran selaku tokoh agama sekaligus imam Desa yang bertempat tinggal di RW 003 dalam wawancaranya.

"mengenai masalah pendidikan politik serta sosialisasi ketika ada pemilihan di RW/RT kami ini, kami hanya dapan informasi dari tokohtokoh agama yang dimana di lakukan dari rumah ke rumah atau bicara langsung di mesjid, hal ini terjadi karena pihak KPU atau lembaga-lembaga politik tidak pernah sampai ke RW/RT kami ini di karenakan akses jalur RW/RT kami kurang baik jalannya dan terkondisi cukuo sedikit penduduknya, makanya mereka tidak pernah sampai kesini" (hasil wawancara dengan Pak Misran).

Berdasarkan dari hasil wawancara diatas penulis dapan menarik kesimpulan bahwa kurangnya partisipasi politik dan pendidikan politik di RW 003 tersebut di akibatkan kurangnya perhatian pemerintah dalam bidang inprastruktur jalan, listrik juga dalam bidan pendidikan, hingga inilah yang menjadi kendala hingga lasan oleh pihak KPU sehingga mereka tidak pernah sampai ke Dusun tersebut untuk sosialisasi ketika adanya pemilihan atau pesta demokrasi.

\section{Partisipasi Masyarakat Desa Mekar Jaya Dalam Pemilihan Presiden Dan Wakil Presiden 2019}

\section{Kampanye di Desa Mekar Jaya}

Kampanye politik merupakan suatu ajang manuver politik untuk menarik sebanyak mungkin pemilih dalam pemilu pilpres 2019 sehingga dapat meraih banyak suara dan kekuasaan. Untuk itu segala cara mungkin akan dipakai dari mulai pemberian janji-janji sampai intimidasi dengan harapan bisa duduk dan berkuasa. Dari pandangan tersebut, kampanye politik merupakan bagian marketing politik yang dirasa penting oleh partai politik menjelang pilpres. Kampanye politik kadang juga dipandang sebagai suatu proses interaksi intensif dari partai politik kepada publik dalam kurung waktu tertentu menjelang pemilihan umum (pemilu), seperti menurut Bardiono dalam wawancara:

"ia mengatakan pada saat itu ia bersama teman-teman di tim sukses ikut serta dalam mengampanyekan andalan mereka berkeliling ke RT/RW tersebut, selain itu ia juga mengatakan momen kampanye pada saat itu cuman sekali dalam lima tahun saja jadi yah asyik saja" (hasil wawancara dengan Bardiono).

Dari definisi ini, kampanye politik adalah periode yang diberikan oleh panitia pemilu kepada semua kontestan untuk memaparkan program-program kerja atau janji-janji yang akan ia lakukan pada saat ia terpilih nanti ini juga dilakukan untuk mempengaruhi opini publik sekaligus memobilisasi masyarakat agar memberikan suaranya pada waktu pencoblosan seperti kata:

\section{Jurnal Sociopolitico}


Pak Martoyo selaku Wakil BPD mengatakan dalam wawancara yang dilakukan peneliti:

"waktu kampanye 2019 kemarin yang lebih banyak bicara di panggung itu rata-rata tim sukses dan para calon kandidat yang cuman bisa bicara saja, jadi beberapa masyarakat yang turut andil dalam kampanye tersebut cuman datang memeriahkan saja bukan datang untuk menyimak apa yang disampaika tim sukses tersebut, ini di karenakan faktor kekecewaan masyarakat terhadap janji-janji palsu yang sampai saat ini tidak terlaksana oleh pemerintah periode kemarin" (hasil wawancara dengan Pak Martoyo).

Keikut sertaan masyarakat dalam memeriahkan kampanye merupakan kesenangan tersendiri bagi individu atau kelompok, apalagi dengan para simpatisan bayaran yang dimana semua kampanye di hadiri demi materi atau uang sogokan dan juga di sertai kesenangan sama dengan Pak Mustakim dalam wawancara yang dilakukan peneliti:

"Semua tim sukses pemilihan predisen dan wakil presiden yang ada bisa dibilang suda saya dapatan uang, jadi bagaimana pun caranya dan berapa pun yang diberikan kepada saya dari setiap tim sukses para calon tetap saja satu calon yang saya pilih tergantung dari berapa besarnya upah yang diberikan”.(hasil wawancara dengan mustakim).
Mendapatkan sesuatu yang CumaCuma walaupun harga yang tidak seberapa tetapi ini merupakan kesenangan juga bagi anak muda yang bernama Rustam yang berkata:

"banyak pernak-pernik kampanye yang diberikan secara CumaCuma dari berbagi bentuk, mulai dari baju kaos, jaket, topi ataupun pin yang saya dapatkan dari kampanye dan juga dari pemberian orang lain meskipun beberapa saya tidak gunakan dan saya pakai".(hasil wawancara dengan Rustam).

Partisipasi masyarakat dalam pemilihan dalam pemilihan presiden dan wakil presiden salah satunya dengan kampanye oleh para calon di tanggapi berbeda-beda oleh individu di suatu masyarakat di Desa Mekar Jaya, Kecamatan Parenggean.

\section{Kondisi Desa Mekar Jaya pada pemilihan Presiden Dan Wakil Presiden 2019}

Kondisi Desa Mekar Jaya pada pemilihan Presiden dan Wakil Presiden tahun 2019 dapat dikatakan aman dan terkendali karena masyarakatnya dan tokoh masyarakat di sana yang turut serta menjaga keamanan dalam proses pemilihan berlangsung, sehingga konflik antara masyarakat yang berbeda calon atau pilihan sama sekali tidak terlihat seperti penuturan Pak Budiono dalam wawancara mengatakan:

"alhamdulillah tahun kmarin pada pemilihan presiden dan wakil presiden partisipasi masyarakat berjalan dengan lancar karena konflik antar pemilih sama sekali tidak ada karena sebelum-

\section{Jurnal Sociopolitico}


sebelumnya suda ada dilakukan penyuluhan dari pihak Panwaslu beserta tokoh-tokoh masyarakat".(hasil wawancara dengan Budiono).

Kondisi keamanan yang baik di Desa Mekar Jaya merupakan bentuk partisipasi politik masyarakat dalam pemilu dalam pilpres 2019 sehingga dengan keamanan yang kondusif dapat memperlancar atau mempermudah dalam memeriahkan pesta Demokrasi.

\section{Bentuk-bentuk partisipasi politik yang terjadi di Desa Mekar Jaya}

Model bentuk pertisipasi politik yang terbangun di Desa Mekar Jaya Pada pemilihan kepala Daerah tersebut adalah :

1) Model Pertisipasi transaksi

Dimana model partisipasi ini lebih kepada dimana suatu masyarakat dalam suatu kegiatan atau menggunakan hak suara mereka itu ketika ada suatu keingina yang ingin mereka capai, seperti halnya yang terjadi di Desa Mekar Jaya pada saat pilpres kemarin, model partisipasi yang terbangun karena adanya sogokan atau money politic, yang diberikan kepada setiap warga oleh setiap tim-tim sukses suatu calon, bukan cuman itu trangsaksi dalam hal pembagian sembako, atribut kampanye dan lain sebagainya juga yang menjadi titik utama atau patokan masyarakat dalam memilih calon kandididat yang akan di pilihnya ketika pada saat hari $\mathrm{H}$ pemilihan. Model partisipasi yang kedua yaitu:

2) Model partisipasi secara Emosional Model partisipasi ini lebih kepada model partisipasi dengan sistem kekeluargaan atau sistem monarki, sistem ini juga lah yang digunakan para tokoh masyarakat di Desa Mekar Jaya dalam memenangkan calon kandidatnya.

Faktor yang Mempengaruhi Partisipasi
Politik Masyarakat di Desa Mekar Jaya

Faktor Rasional

Pendekatan rasional yaitu melihat bahwa pemilih akan menentukan pilihannya berdasarkan penilaiannya terhadap isu-isu politik dan kandidat yang diajukan, artinya para pemilih dapat menentukan pilihannya berdasarkan pertimbangan-pertimbangan rasional.

Perilaku pemilih berdasarkan pertimbangan rasional tidak hanya berupa memilih alternative yang paling menguntungkan (makximum gained) atau mendatangkan kerugian yang paling sedikit, tetapi juga dalam memilih alternative yang menimbulkan resiko yang paling kecil yang penting mendahulukan selamat. Oleh karena itu, diasumsikan para pemilih mempunyai kemampuan untuk menilai isu-isu politik yang diajukan, begitu juga mampu menilai calon kandidat yang ditampilkan. Penilaian rasional terhadap isu politik atau kandidat ini dapat didasarkan pada jabatan, informasi dan pribadi yang populer atau prestasi yang dimilikinya seperti penuturan Pak Atim.

"waktu pemilihan presiden dan wakil presiden tahun 2019 saya memilih Jokowidodo dan Maruf Amin karena secara pendidikan, pengetahuan serta hubungan emosional terhadap masyarakat menurut saya dialah yang pantas, di tambah dengan penilaian kami terhadap beliau mengenai kepribadian nya juga degan isu-isu politik yang pernah ia lakukan dan 
pokoknya baguslah untuk pilpres 2019 ini". (hasil wawancara dengan Atim).

Pendekatan rasional berasumsi bahwa pemilih merupakan kegiatan yang otonom, dalam arti tanpa desakan dan paksaan dari pihak lain. Namun dalam kenyataan dalam negara-negara berkembang perilaku memilih bukan hanya ditentukan oleh pemilih sebagaimana pendekatan rasional, tetapi dalam banyak hal justru ditentukan oleh tekanan kelompok, intimidasi, dan paksaan dari kelompok atau pemimpin tertentu.

\section{Faktor Psikologis}

Faktor psikologi merujuk pada persepsi pemilih atau keterkaitan emosional terhadap partai atau calon tertentu seperti yang di ungkapkan Pak Amir

\section{"dari dulu sampai sekarang saya pilih PDI Perj uangan jadi siapa pun yang menjadi presidennya saya tetap pilih yang dari partai PDI Perjuangan".(hasil wawancara dengan Amir).}

Sangat jelas apa yang dikatakan Pak Amir bahwa faktor pisikologislah yang mempengaruhinya dalam memilih di mana pun.

\section{Faktor Sosiologi (primordialisme)}

Primordialisme adalah paham atau ide dari anggota masyarakat yang mempunyai kecenderungan untuk berkelompok sehingga terbentuklah sukusuku bangsa. Pengelompokkan ini tidak hanya pembentukan suku bangsa saja, tetapi juga dibidang lain, misalnya pengelompokkan berdasarkan ideologi agama dan kepercayaan.

Primordialisme oleh sosiologi digunakan untuk menggambarkan adanya ikatan-ikatan seseorag dalam kehidupan sosial dengan hal-hal yang dibawah sejak awal kelahiran terhadap suku bangsa, daerah kelahiran, ikatan-ikatan dan agama.

Primordialisme adalah paham atau ide dari anggota masyarakat yang memiliki kecenderungan untuk berkelompok berdasarkan suku-suku bangsa. SARA (suku, agama, ras dan antar golongan) sejatinya adalah bagian dari fakta sejara atau berdirinya republik ini. Indonesia lahir dari rahim kebhinekaan, dimana SARA merupakan salah satu bagia terpentng dari komponen kemajemukan sebuah bangunan bangsa.

\section{Prospek Partisipasi Masyarakat Desa Mekar Jaya di masa Depan}

Partisipasi politik dan faktor yang mempengaruhi pemilih untuk memilih calon Presiden dan Wakil Presiden, Kecamatan Parenggean, bermacammacam dalam berpartisipasi pada pilpres 2019 kemarin dan berbagai faktor yang mempengaruhi pemilih untuk memilih calon Presiden dan wakil presiden partisipasi masyarakat dalam bentuk menjaga keamanan agar kondusif, ikut kampanye dan memilih calon presiden dan wakilpresiden di TPS yang telah ditentukan, merupakan beberapa bentuk partisipasi masyarakat di Desa Mekar Jaya, Kecamatan Parenggean. Faktor yang mempengaruhi pemilih di Desa Mekar Jaya, Kecamatan Parenggean, dalam memilih sangat dipengaruhi beberapa faktor yang sangat sulit untuk dipengaruhi oleh orang lain yang dimana faktor sosiologis dan fisikologis merupakan beberapa paktor yang mempengaruhi

\section{Jurnal Sociopolitico}


beberapa masyarakat di Desa Mekar Jaya, berbeda dengan faktor rasional yang dimana masyarakat dapat dipengaruhi dalam memilih pilihannya yang berupa sembako dan uang (money politic) dari tim sukses para calon presiden dan wakil presiden.

Partisipasi politik masyarakat Desa Mekar Jaya dimasa depan untuk pemilu 2019 tidak akan berbeda jauh dengan pemilu 2014, karena hanya beberapa warga masyarakat yang menggunakan hak suaranya memilih presiden dan wakil presiden yang tanpa ada paksaan dari pihak lain. Money politic akan tetap menjadi andalan bagi para tim sukses calon presiden dan wakil presiden untuk mendapatkan suara yang sebanyakbanyaknya dalam pemilu, selain politik pencitraan dari para calon presiden dan wakil presiden.

\section{Kesimpulan}

a) Pendidikan serta partisipasi politik masyarakat di Desa Mekar Jaya Kecamatan Parenggean Kabupaten Kotawaringin Timu Terbilang kurang baik karena kurangnya masyarakat ikut serta dalam menggunakan hak suara mereka diakibatkan tingkat pendidikan serta partisipasi politik masyarakat di Desa Mekar Jaya tersebut kurang memahami apa itu pesta demokrasi yang sebenarnya, mereka lebih memilih golput tidak menggunakan hak suara nya di bandingkan ikut serta dalam pemilihan. Dalam bidang keamanan, ikut dalam penyuluhan, dan ikut serta dalam kampanye serta pemilihan Presiden dan Wakil Presiden 2019 di Desa Mekar Jaya terbilang baik, walaupun pilihan masyarakat berbeda-beda yang dipengaruhi beberapa faktor yakni faktor pendekatan struktural yang melihat kegiatan memilih sebagai produk dari konteks struktur yang lebih luas, seperti struktur sosial, pendidikan politik, sistem partai, sistem pemilihan umum, permasalahan, dan program yang di tonjolkan oleh setiap partai.

b) Faktor- faktor yang mempengaruhi partisipasi politik yang kaitannya dengan konteks sosial. Kongkretnya, memilih seseorang dalam pemilihan umum dipengaruhi latar belakang demografi dan sosial ekonomi, seperti jenis kelamin, tempat tinggal (kotadesa), pekerjaan, pendidikan, kelas, pendapatan dan agama. Faktor fisikologi merujuk pada persepsi pemilih atas partai-partai yang ada atau keterkaitan emosional pemilih terhadap partai tertentu serta faktor pendekatan rasional melihat kegiatan memilih sebagai produk kalkulasi untung dan rugi. Yang di pert imbangkan $\mathrm{t}$ idak hanya "ongkos" memilih dan memungkinkan suaranya dapat mempengaruhi hasil yang diharapkan tetapi juga melihat alternatif lain yang menguntungkan. Tiga faktor diatas yang mempengaruhi pilihan masyarakat Desa Mekar Jaya dalam pemilihan Presiden dan Wakil Presiden 2019.

\section{Referensi}

Asdar, Muhammad. Partisipasi Politik masyarakat Kecematan kindang Dalam Pemilu Kada (Bupati) Putaran Ke II tahun 2010 Kabupaten Bulukumba, Universitas Islam Negeri Alauddin Makassar, 2010

\section{Jurnal Sociopolitico}


Arikunto, Suharsimi. Prosedur Penelitian Suatu Pendekatan Praktik. (Edisi Revisi IV), Jakarta: PT Rineka Cipta, 2006

Sapti, Aan. " Partisipasi Politik Dalam Pemilu Dikabupaten Magelang 2015 ",Mahasiswa dari Universitas Negeri Semarang, 2010

Bappenas dan Depdagri. Pedoman Penguatan Pengamanan Program Pembagunan Daerah. 2002.

Budiarjo, Miriam. Dasar-Dasar Ilmu Politik, Gramedia Pustaka Utama Jakarta, 2008.

Baco, Sabir. Partisipasi politik Masyarakat Dalam Pemilihan Presiden dan Wakil Presiden 2009 di Kelurahan Sunggu Minasa.

Bungin Burhan,S . Sos., M. Si., Komunikasi, Ekonomi, Kebijakan Publik, dan Ilmu Sosial. Jakarta : Kencana Prenada Media Group, 2007

Christina, Hostz-Bacha. Political Disaffection, dalam Lynda Lee Kaid and Christina Holttz-Bacha, Encyclopedia of Political Communication, (California : Saga Publications), 2008

Demsi Intan Kamar, Potret Pendidikan Indonesia Dalam Deretan Masa. Yabuindo Pers , 2015. Demsi Intan Kamar, Potret Pendidikan Indonesia Dalam Deretan Masa. Yabuindo Pers , 2015.

Prof. Budiarjo Miriam, Dasar-Dasar Ilmu Politik Edisi Refisi, Gramedia Pustaka Utama, 2008

Garcia Oscar Luengo, E-Activism New Media and Political Participation in Erope, London, 2006

Hendri, Koeswara." Partisipasi Politik Perempuan Dalam Pemilu Pada Pilkada Di Sumatera Barat 2005 “,
Universitas Andalas Sumatera Barat, 2007

Harrop, Martin dan William Miller, Election and Voters (A Comparative Interoduction), London: The Macmillan Press Ltd, 1987

Huntington, Samuel. dan Joan Nelson, Partisipasi Politik di Negara Berkembang, (Jakarta: Rineka Cipta, 1990)

Imawan, Riswanda. dan Affan Gaffar,: Analisi Pemilihan Umum 1992 di Indonesia, Yogyakarta : Laporan Penelitian Fakultas ISIPOL, Universitas Gadjah Mada, 1993.

M. Mujtahid Iqbal, Pendidikan Politik Terpadu Bagi Masyarakat Menuju Pemilu 2014 Sesuai dengan Prinsip Transparansi Dan Akuntabilitas 2013

M. Sirozi, Ph.d. Politik Pendidikan. PT Raja Grapindo Persada, 2005

Polidano, C., "Why Bureaucrats Can't Always Do What Ministers Want: Multiple Accountabilities in Westminster Democracies." Public Policy and Administration 13, No. 1, 1998.

Subakti, Ramlan. Memahami Ilmu Politik, Jakarta : PT Gramedia Widiasarana Indonesia, 1995

Riswanda. Muhammad Asfar, Surabaya : Pemilu dan Perilaku Memilih, Pustaka Eureka, 2006

Widjaja Haw, 1996, Pemerintahan Desa Dan Administrasi Desa, (Jakarta,PT. Raja Grafindo)

Yatim, Badri, 1993. Sejarah Peradaban Islam (Dirasah Islamiyah II), Jakarta :PT.Raja Grafindo Persada. 